\title{
LUMINESCENCE DATING OF THE SEDIMENTS FROM A BURIED CHANNEL LOOP IN FATEHABAD AREA, HARYANA: INSIGHT INTO VEDIC SARASWATI RIVER AND ITS ENVIRONMENT
}

\author{
H. S. SAINI and S. A. I. MUJTABA \\ Geological Survey of India, Faridabad, 121001
}

Received 3 February 2010

Accepted 15 September 2010

\begin{abstract}
Geomorphology and sedimentary composition of an archeologically important palaeochannel segment of the Vedic Saraswati River in northwestern Haryana have been evaluated and its temporal relation with the surrounding upland examined with the help of OSL dating. Sediment composition and OSL ages suggest that the channel received enough water supply between 5.9 and $4.3 \mathrm{ka}$ ago, and even before. Several lakes and ponds had developed during this period in the surrounding areas. It was a wet phase in this area as well as in Rajastahn. After $\sim 4.3 \mathrm{ka}$, the river got starved of regular water supply, became sluggish and finally dried up. Reduced water supply, indicative of decreased rainfall, occurred between 4.3 and $3.4 \mathrm{ka}$ ago. The environmental history of the channel might have influenced the Harrapan archeology of the area.
\end{abstract}

Keywords: Northwestern Haryana, Vedic Saraswati, Palaeoenvironment

\section{INTRODUCTION}

The northwestern Haryana Plains are constituted by over $400 \mathrm{~m}$ thick column of Late Quaternary alluvial sequences covered with aeolian sediments, constituting the northeastern fringe of the Thar Desert (Thussu, 1995; Saini and Anand, 1996; Fig. 1). The area experiences arid to semi-arid climate and drained by Ghaggahar River, which originates in Siwalik ranges and disappears in northern tip of the Thar Desert. Drainage disorganization and disappearance of Harappan society are the two important issues associated with these plains. The first issue concerns the Vedic river Saraswati, mentioned in Rigveda as a mighty Himalayan river of the vedic period. It does not exist now. The second issue is related to the disappearance of Harappan civilisations whose mounds are scattered on these plains (Fig. 1; Joshi et al., 1984). Harappan or the Indus civilization was one of the four great urban civilizations of the world that is believed to have flourished between around 2700-1700 BC in the valleys of Indus and Ghaggar-Hakara systems. The ancient Saraswati river is also believed to have existed during this period. Some important mounds of these civilizations in the present area occur at Wannawali and

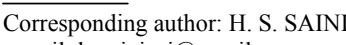

e-mail: hssainigsi@gmail.com
Rakhigarhi. The natural or anthropogenic causes of their disappearance are not comprehensively known.

The course of the Vedic Saraswati was first surveyed by an archaeological expedition (Stein, 1942). Later, it was investigated by Oldham (1893) and Wilhelmy (1969). After about a century, the issue regained attention leading to several remote sensing based studies (Yash Pal et al., 1980; Sood and Sahai, 1983; Ghose et al., 1979; Sahai, 1999; Gupta et al., 2004; Radhakrishna and Merh, 1999; and references therein). Maps of palaeodrainge including old channels of Saraswati and archaeological mounds in northwestern India have been prepared and discussed. However, most of the inferences remained unsubstantiated due to the lack of geomorphological truths, sedimentological characters and absolute ages of the buried channels. The important questions yet to be resoled are: 1) whether any such river ever existed, 2) if yes, the time and duration, 3) the course of the river and 4) causes of its disappearance.

Most of the previous studies show a prominent loop like zone in Fatehabad area as an important segment of the Saraswati palaeocourse (Yash Pal et al., 1980). The loop stands out as high moisture zone in aerial photos and imagery (Fig. 1). It is usually dry but flooded when rainfall exceeds $800 \mathrm{~mm}$, as last happened in 1996. In the imagery, the zone extends westward from Fatehabad and joins the floodplains of Ghagghar. In the field, the ex- 
tended part is differentiable by clay dominated surface against the sandy surface of the surroundings. This study evaluates the ground geomorphology of the area and reconstructs the environmental history of the palaeochannel with the help of OSL dates which may provide a clue to the understanding of the Harappan history.

\section{FIELD STUDIES AND SAMPLING}

Morphology of the palaeochannel was mapped by taking field traverses along and across the high moisture loop. The southern bluff line representing the palaeobank of the channel was identified between Fatehabad and Hosanga as shown by bold line in Fig. 1. The bluff line is represented by $\sim 5 \mathrm{~m}$ high scarp which separates the palaeochannel from the surrounding upland. West of Fatehabad and east of Hosanga, the sharpness of the bluff line was found to disappear gradually. The northern bluff line could not be precisely mapped due to the absence of discernable scarp, therefore it was marked by a dashed line. Other features noted to demarcate the loop zone included a low lying plain topography, clayey topsoil lithology, absence of dunes, fresh ground water and flood prone nature. The surrounding upland, on the other hand, showed an abundance of dunes, rugged topography, sandy ground lithology and saline ground water.

Sedimentary assessment of palaeochannel and upland was acquired through the study of sections in pits, wells and canal diggings. Gross lithological characters were used to interpret the depositional environments of the sediment layers. Two sections in palaeochannel near Razabad village (L1 \& L2) and three on the upland near Hosanga (L3), Bhutha Kalan (L4) and Jhalania (L5) were sampled for OSL dating. OSL samples of sand were taken in $8 " \times 2$ " stainless steel tubes while finer sediments were collected in 10 " $\mathrm{x} 2.5$ " tubes from freshly exposed surfaces. OSL ages of 11 samples were deter- mined. Lithology of a few shallow bore-hole were collected from surrounding areas.

Based on the topographic, lithologic and OSL age data, a geomorphological and stratigraphic reconstruction was developed along NW-SE line.

\section{OSL DATING}

The middle part from each sample tube was selected to determine the depositional ages by OSL technique (Aitken, 1985 and 1998). The outer parts were used for dose rate and water content measurements. A selected portion was treated with $1 \mathrm{~N} \mathrm{HCl}$ solution to remove the carbonates and $30 \% \mathrm{H}_{2} \mathrm{O}_{2}$ to remove organic impurities. The dried sediments were sieved to separate a 90-150 $\mu \mathrm{m}$ grain size fraction from which quartz grains were separated using a sodium polytungstate solution of $2.58 \mathrm{~g} / \mathrm{cm}^{3}$ specific density. The $20 \mu \mathrm{m}$ outer layer of quartz grains was removed by etching with $40 \%$ HF for 80 minutes and then by HCL for 20 minutes. This was done to remove feldspars and the alpha irradiated layer.

The quartz grains were temporarily mounted on stainless steel discs (9.6 mm diameter) as a monolayer, generally over a circular area of $4 \mathrm{~mm}$ diameter with the help of silicon spray. Luminescence measurements were carried out using a Risoe TL/OSL Reader 15-20 DA, equipped with a calibrated $\mathrm{Sr}-90$ beta source. The stimulation was made using blue LED's $(470 \pm 30 \mathrm{~nm})$ and the luminescence was detected in the UV range through a Hoya UV-340 filter placed in front of an EMI9671 photomultiplier tube. Luminescence was recorded in 250 channels (40 s) in which counts of first five channels were considered for further calculation after subtracting background counts of the last 25 channels.

The aliquot discs were placed in alternating holes of the sample carousel to avoid irradiation/stimulation crosstalk. Generally four pre-dating tests were conducted on

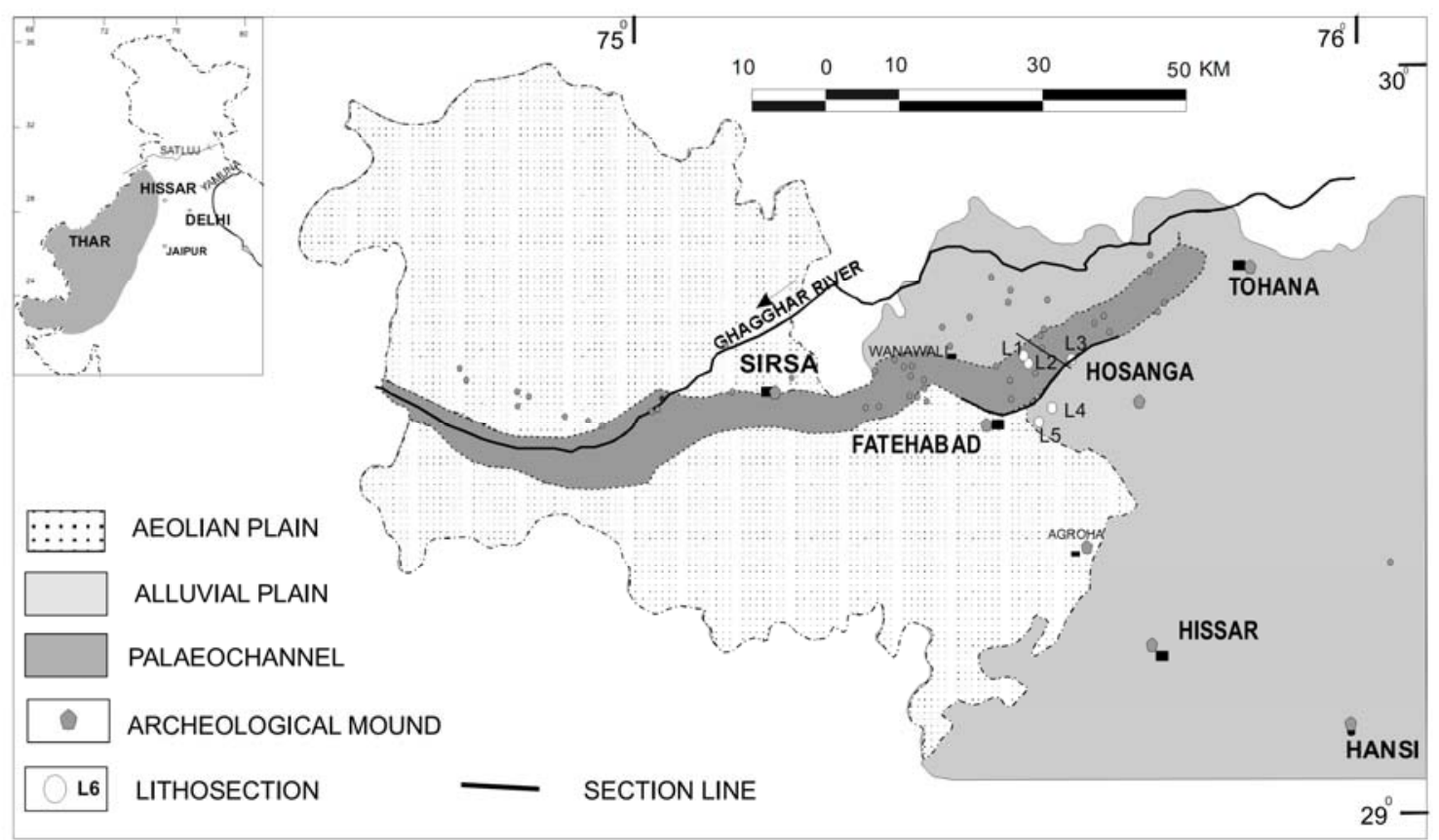

Fig. 1. Simplified geomorphological map of the northwestern part of Haryana. The Aeolian plain on west constitutes the northeastern fringe of the Thar desert. The palaeochannel zone has a marked southern bluff between Fatehabd and Hosanga. Section line and locations of studied sections are also shown. 
each sample before actual measurement of $D_{e}$. These included feldspar screening, rough dose estimation, preheat plateau test and dose recovery test. When feldspar signals were recorded, the sample was retreated with HF. Generally the IRSL/OSL ratio was kept below $1 \%$. Nevertheless, an additional step of IRSL at $75^{\circ} \mathrm{C}$ per sec for $100 \mathrm{sec}$ was given before each blue OSL measurement. Blue light stimulation was carried out at $125^{\circ} \mathrm{C}$ for $40 \mathrm{~s}$.

A preheat temperature of $220^{\circ} \mathrm{C}$ for $10 \mathrm{~s}$ and $\mathrm{TL}$ of $180^{\circ} \mathrm{C}$ (in-lieu of preheat) were found suitable. The heating rate used was $5^{\circ} \mathrm{C} / \mathrm{s}$. The dose recovery was within $\pm 10 \%$ of the administered dose.

The equivalent dose $\left(D_{e}\right)$ was measured following the Single Aliquot Regeneration (SAR) protocol (Murray and Roberts, 1998; Murray and Wintle, 2000; Wintle and Murray, 2006). Sample discs with recycling ratio within $10 \%$ and recuperation of less than $5 \%$ were considered for final calculation of the $\mathrm{D}_{\mathrm{e}}$ values. The commercial software "Analyst" was used for the calculation of individual $D_{e}$ values. Calculation of $D_{e}$ 's was repeated from the spreadsheets provided by A.S. Murray, Risoe National Laboratory, Denmark. It was found that average $D_{e}$ values of well bleached samples were similar in both calculations. The spreadsheets were helpful in discriminating the recuperation, sensitivity changes and recycling ratio.

The growth curves and distribution pattern of $D_{e}$ values of some samples representing variations are shown in
Fig. 2. The samples had near normal distribution of $D_{e}$ values, therefore, weighted averages were employed for age calculation using Grun software. The dose rates $\left(D_{r}\right)$ of samples were calculated from the concentration of $U$ and Th (analyzed by ICP-MS at the Chemical Laboratory, GSI, Hydrabad) and K (by flame photometer at Chemical Labs, GSI, Faridabad). The OSL ages are compiled in Table 1.

\section{LITHO-SECTIONS IN PALAEOCHANNEL LOOP}

Two sections in Rangoi canal digging near Razabad village were selected for sampling. Both sites, around 500 $\mathrm{m}$ apart, showed matching lithological arrangement except varying thickness of the sediment layers. They revealed four gradational layers of a fining upward alluvial sequence (Fig. 3). Layer-1, at the top, is a bed of hard, pink clay that forms the ground surface of the palaeochannel. It is thinly laminated. Layer-2 is pinkish and massive to faintly laminated silty-clay, slightly coarser than the layer-1. Layer-3 sediments are of intermediate granularity between layer 4 and 2 . It is formed by siltysand in the lower part and sandy-silt in the upper part. Layer-4 comprises light grey fine sand with an oxidized top. In nearby bore wells, it is reported to continue up to $\sim 8 \mathrm{~m}$ depth. Layer-4 represents an active stream channel, layer-3 with increasing proportion of mud denotes a de-
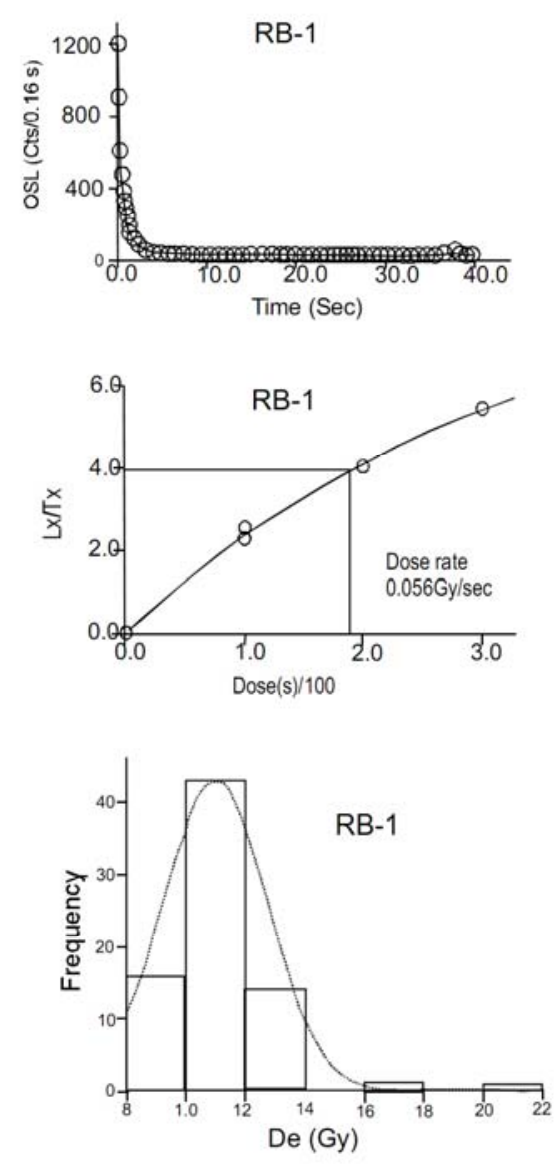

RB-8
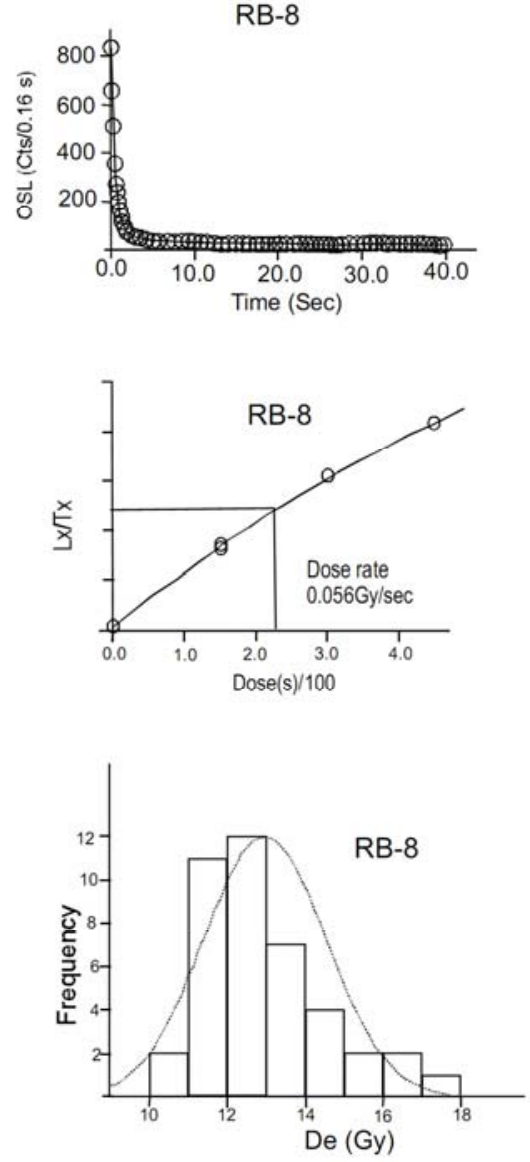

$\mathrm{JH}-1$
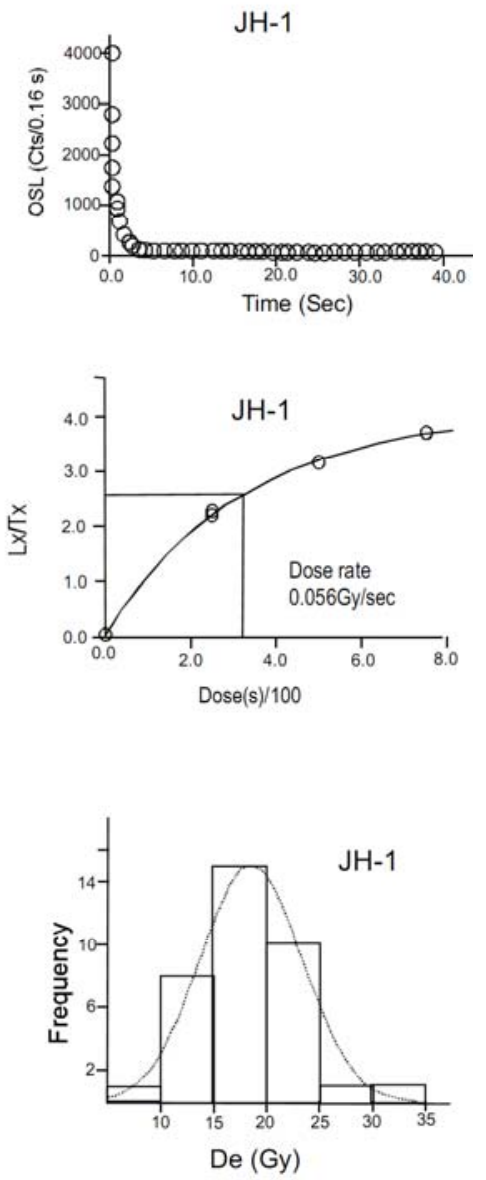

Fig. 2. Shine down curves, growth curves and histograms of three representative samples. 


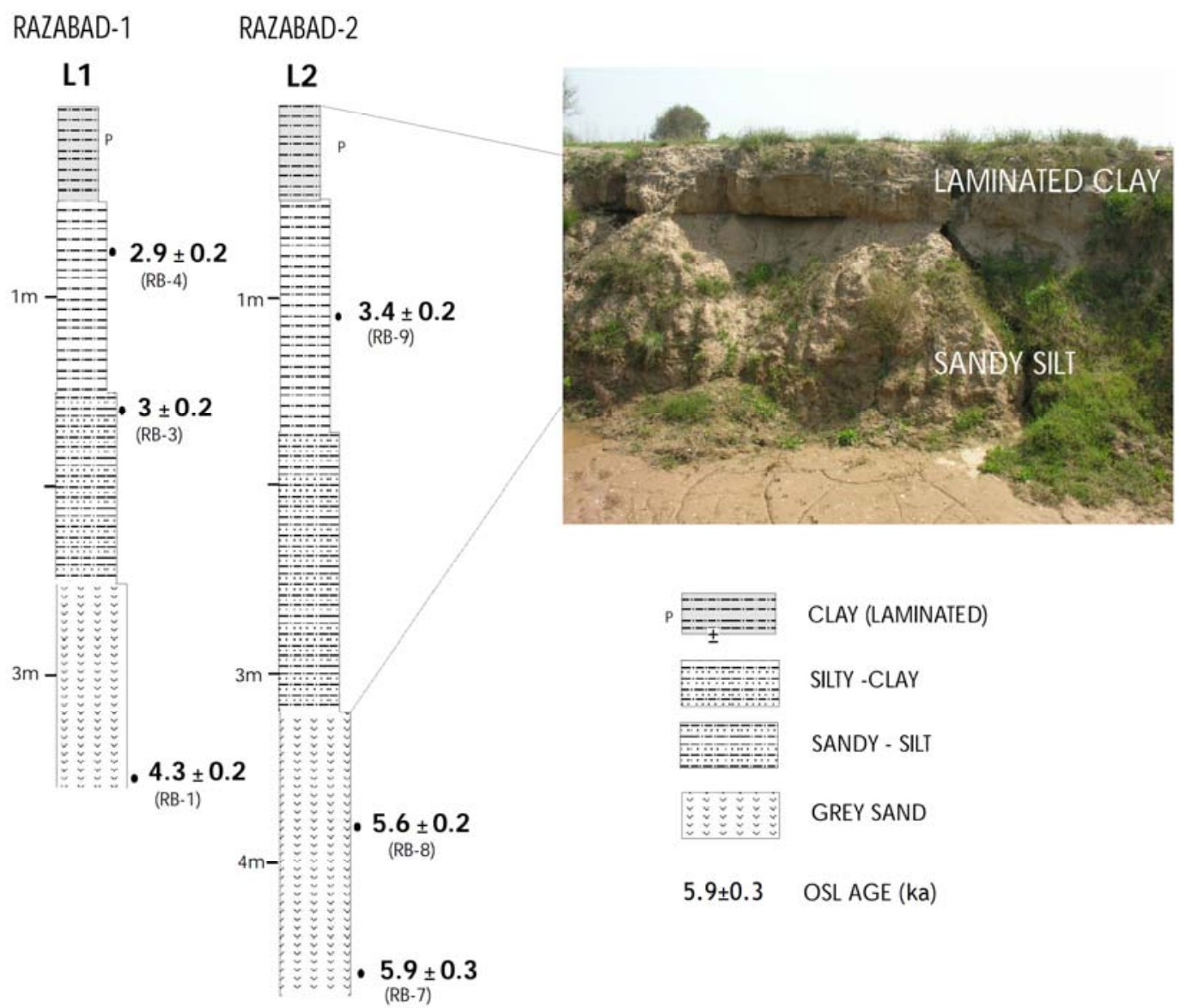

Fig. 3. Lithologs of two nearby sections in palaeochannel near Razabad with OSL ages. A field photo of the canal digging exposing fine sequence is also shown. The channel sand lies below the floor of canal digging.

generating phase of the channel, layer-2 represents a further worsening and layer- 4 is indicative of a defunct channel with ephemeral lacustrine like condition as today.

\section{OSL Chronology of Razabad Sections}

The samples at $3.5 \mathrm{~m}$ depth (RB-1) from sand of layer- 4 has yielded an age of $4.3 \pm 0.2 \mathrm{ka}$ while the sample
RB-7 from the same layer but at a slightly greater depth $(4.7 \mathrm{~m})$ has given an age of $5.9 \pm 0.3 \mathrm{ka}$ (Fig. 3). On the basis of these ages, it can be inferred that this channel was active between $\sim 6$ and $4.3 \mathrm{ka}$, for about $2000 \mathrm{yrs}$. In the absence of dates from the true base of the channel sand, its history older than 6 ka can not be commented upon. The oldest age from the overlying channel mud is $3.4 \pm 0.2 \mathrm{ka}$ (RB-9), which implies that by this time the

Table 1. Analytical details and OSL ages of samples used in this study.

\begin{tabular}{|c|c|c|c|c|c|c|c|c|c|}
\hline Sample & $\begin{array}{l}\text { Depth } \\
\text { (m) }\end{array}$ & $\underset{(\mathrm{ppm})}{U}$ & $\begin{array}{c}\text { Th } \\
\text { (ppm) }\end{array}$ & $\begin{array}{c}K \\
(\%)\end{array}$ & $\begin{array}{c}\text { Water } \\
\text { content } \\
(\%)\end{array}$ & Aliquots & $\begin{array}{c}\text { Dose rate } \\
\text { (Gy/ka) }\end{array}$ & $\begin{array}{c}\text { Average De } \\
\text { (Gy) }\end{array}$ & Age (ka) \\
\hline \multicolumn{10}{|c|}{ Hosanga } \\
\hline HS-3 & 1 & 2.41 & 12.96 & 1.55 & $10 \pm 5$ & 32 & $2.9 \pm 0.2$ & $35 \pm 2$ & $12 \pm 1$ \\
\hline HS-2 & 3 & 3.06 & 13.1 & 1.75 & $10 \pm 5$ & 35 & $3 \pm 0.1$ & $49 \pm 1$ & $15.4 \pm 1$ \\
\hline HS-1 & 4 & 2.69 & 13.55 & 1.93 & $15 \pm 5$ & 47 & $3 \pm 0.1$ & $62 \pm 1$ & $20 \pm 1$ \\
\hline \multicolumn{10}{|c|}{ Jhalania } \\
\hline $\begin{array}{l}\mathrm{JH}-1 \\
\text { Bhuth }\end{array}$ & $\begin{array}{l}0.35 \\
\text { alan }\end{array}$ & 2.68 & 14.68 & 1.75 & $15 \pm 5$ & 36 & $2.97 \pm 0.1$ & $19 \pm 1$ & $6.4 \pm 0.4$ \\
\hline $\begin{array}{l}\text { BK-1 } \\
\text { Raz }\end{array}$ & 0.7 & 2.97 & 14.2 & 1.83 & $10 \pm 5$ & 34 & $3.2 \pm 0.17$ & $28.1 \pm 0.5$ & $8.7 \pm 0.5$ \\
\hline RB-4 & 0.8 & 2.36 & 12.56 & 1.7 & $10 \pm 5$ & 25 & $3.01 \pm 0.2$ & $8.8 \pm 0.3$ & $2.9 \pm 0.2$ \\
\hline RB-3 & 1.6 & 2.9 & 15.16 & 1.55 & $10 \pm 5$ & 57 & $2.98 \pm 0.14$ & $9.06 \pm 0.2$ & $3 \pm 0.2$ \\
\hline RB-1 & 3.6 & 2.44 & 12.50 & 1.2 & $10 \pm 5$ & 75 & $2.4 \pm 0.1$ & $10.5 \pm 0.2$ & $4.3 \pm 0.2$ \\
\hline RB-9 & 1.3 & 2.67 & 15.75 & 1.4 & $10 \pm 5$ & 41 & $2.87 \pm 0.1$ & $9.8 \pm 0.1$ & $3.4 \pm 0.2$ \\
\hline $\mathrm{Rb}-8$ & 3.6 & 2.44 & 12.10 & 1.05 & $10 \pm 5$ & 41 & $2.27 \pm 0.1$ & $12.9 \pm 0.3$ & $5.6 \pm 0.2$ \\
\hline RB-7 & 4.7 & 2.89 & 5.86 & 0.8 & $10 \pm 5$ & 40 & $2.23 \pm 0.1$ & $13.3 \pm 0.3$ & $5.9 \pm 0.3$ \\
\hline
\end{tabular}


nature of the stream had gradually changed from a bed load to a suspended load. Since than, it has been a defunct channel witnessing infrequent ponding during heavy rains.

\section{LITHOLO-SECTIONS IN SURROUNDING UPLAND}

\section{Hosanga Section}

This is an important section situated on the bluff of the palaeochannel of the Vedic Saraswati in Fatehabad district. The section was selected to examine whether the palaeochannel sediments are younger/older or of the same age than the regional upland plain and whether any fluvial activity younger than that of the upland existed in the palaeochannel zone. The section revealed a simple lithological structure with an aeolian unit at the top, followed by an alluvial unit downward of unconfirmed thickness. The aeolian unit is around $2.5 \mathrm{~m}$ thick and is expressed as a remnant hump on the ground. The sand is buff, well sorted with small pottery pieces embedded in

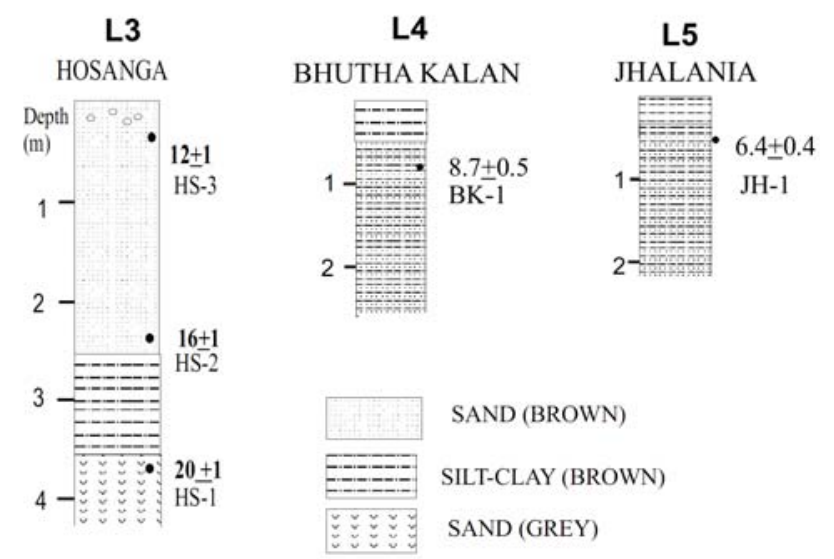

Fig. 4. Lithologs from three sections on upland with OSL ages. For locations, please refer Fig. 1. the top $20 \mathrm{~cm}$. The buff sand grades downward in the silt and silty clay constituting the uppermost layer of alluvial unit. The silt clay is underlain by loose, grey fluvial sand, coarser and more micaeous than layer-4 sand of the palaeochannel (Fig. 4).

\section{OSL Chronology of Hosanga Section}

The age of the base of aeolian unit is $16 \pm 1 \mathrm{ka}$ (HS-2) and of the top is $12 \pm 1 \mathrm{ka}$ (HS-3) (see section L-3, Fig. 4). The underlying grey fluvial sand has produced an age of $20 \pm 1 \mathrm{ka}$ (HS-1) which suggests the existence of an alluvial phase older than the layer-4 fluvial phase of the palaeochannel.

\section{Jhalnia-Bhutha Kalan Sections}

These two sections were studied to determine the age of the topmost bed of the sediment column of the regional upland (L4 and L5, Fig. 4). At both places, there is a 20$50 \mathrm{~cm}$ thick bed of silty clay at the top underlain by brown sandy silt with pea-sized carbonate nodules. The lithology appears to represents deposits of an ephemeral stream. At both locations the sandy silt was sampled for OSL dating.

\section{OSL dates of Jhalnia and Bhuta Kalan Sections}

The sample from Bhuta-Kalan from a depth of $0.7 \mathrm{~m}$ from the ground gave an age of $8.7 \pm 0.5 \mathrm{ka}$ (BK-1) while the sample from Jhalnia at $0.35 \mathrm{~m}$ depth showed an age of $6.4 \pm 0.4 \mathrm{ka}$ (JH-1) (Fig. 4). These samples lie at almost the same level of HS-3, but show much younger ages of deposition. It shows that after the aeolian deposition of Hosanga, the area witnessed some ephemeral alluvial activities which deposited finer sediments in the interdunal areas.

\section{SEDIMENTRY EVOLUTION AND ENVIRON- MENT}

The NW-SE section elucidates the geomorphic signature of a desiccated stream channel (Fig. 5), which has

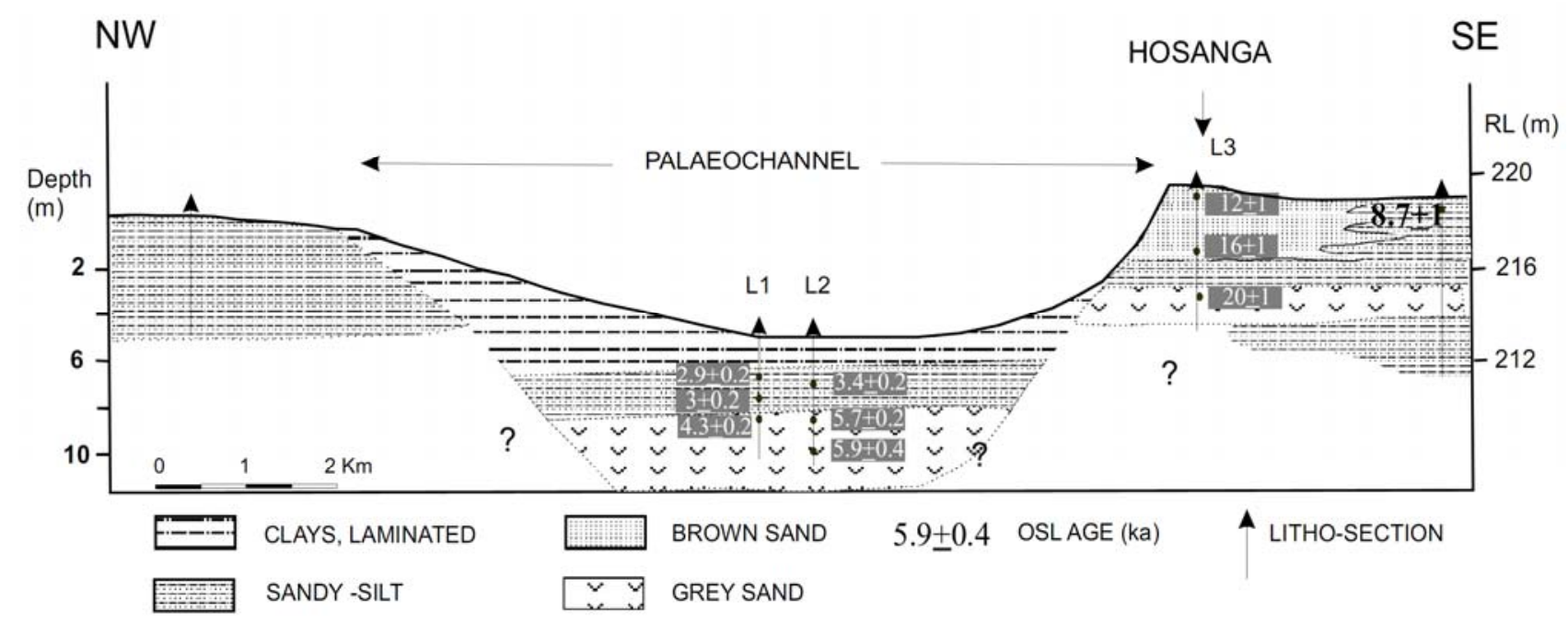

Fig. 5. NW-SE section across the palaeochannel showing its geomorphology and shallow lithological architectures. The landform and OSL ages of channel and upland sediments are also given which confirm a younger status for the palaeochannel sediments. 
been referred as a part of Vedic Saraswati River by previous workers. This segment has a sharp southern bank and a gradual northern bank whose upstream and downstream continuity is not fully confirmed. The section also shows that the sediments of upland surface are older than those in the palaeochannel and confirms the existence of a younger phase of fluvial activity. The upward fining of sediments in the palaeochannel is an evidence of progressively reducing water supply to the stream and can be interpreted in terms of declining rainfall. The sand at the lower part of the section represents an active channel whose detritus supply was ensured by rains higher than today. With the help of OSL dates a part of this wet phase can be conclusively constrained between $\sim 5.9 \pm 0.3$ and $4.3 \pm 0.2 \mathrm{ka}$, and even before. It means that for $\sim 2000 \mathrm{yrs}$, during Mid-Holocene, northwestern parts of Haryana as well as the catchment of the palaeoriver had witnessed a wet climate. The inference is corroborated by numerous carbonate lake deposits in western and central parts of Haryana, especially in Riwasa-Charkhi Dadri area (Bhatia and Singh 1988; Saini et al., 2005). The argillaceous limestone in these lakes was precipitated between $6238 \pm 37$ and $4491 \pm 35{ }^{14} \mathrm{C}$ yr BP (Pant et al., 2005), under wet and warm conditions. The Lunkaransar lake in northern Rajastan also witnessed high water level between 6300 and $4800{ }^{14} \mathrm{C}$ yr BP (Enzel et al., 1999), and so did the other lakes in Rajastan (Singh et al., 1974 and 1990). Based on these data, it is possible to suggest that summer monsoons were much stronger during MidHolocene over a large area of the Thar desert and its northeastern fringe in Haryana. Such conditions appear to have changed some times between 4.3 and $3.4 \mathrm{ka}$, when Fatehabad palaeochannel was transformed from a bed load to a vigour-less suspended load stream due to decreased rainfall. The oxidized top of channel sand and decreasing grain size of overlying sediments indicate an increasing role of aridity and decreasing carrying capacity of the stream. It can be safely estimated that after $\sim 3.4 \mathrm{ka}$ and up to $2.9 \mathrm{ka}$ the rains had reduced substantially. As a result the Fatehabad channel gradually became defunct and was receiving only fine clay sediments during episodic heavy rains. This wet phase of Mid-Holocene could be a congenial period to support and sustain large agriculture-based population whose remains are scattered close to the palaeochannel (Fig. 1). Some absolute dates from these archaeological mounds would be helpful in establishing the relation between the history of Fatehabd channel and Harrapans.

At this stage, it is difficult to comment on the source and catchment area of the palaeochannel as to whether it originated in glaciated higher Himalayas as envisaged. With available nature of sediments up to $4.5 \mathrm{~m}$ having an apparent deficiency of mica, the channel appears more of a piedmont origin like the present day Gahgghar. Wellbleached luminescence behaviour of quartz is more akin to the locally reworked sediments. This point, however, needs detailed mineralogical investigations.

The $20 \pm 1-12 \pm 1 \mathrm{ka}$ age brackets for upper $4 \mathrm{~m}$ part of the sediments column at Hosanga conclusively make this surface older than the palaeochannel. The top sediment layer from Jhalania and Bhutha Kalan also pre-dates the palaeochannel sediments and supports the existence of a younger fluvial activity in the channel, which was identified from remote sensing only.

\section{CONCLUSIONS}

1) The high moisture loop in Fatehabad area, whose geomorphic signatures are confirmed in this study, is the remnant of a stream channel which actively existed during $\sim 6-4 \mathrm{ka}$ and before. A reduced discharge led to its degeneration sometime between $\sim 4$ and 3.4 ka. Since then, this relict has been dry and witnessed lacustrine conditions under abnormally high rains.

2) A wet phase prevailed in northwestern Haryana during Mid-Holocene, which sustained the streams and lakes in the area and possibly the Harrapans.

\section{ACKNOWLEDGEMENTS}

We thank Dy. Director General, Geological Survey of India, Northern Region for facilities, Sh R.K Khorana, (then Director) for his supervision and Dr Anil Joshi (Director) for fruitful discussions. Prof A.K. Singhvi consistently encouraged and motivated to complete the write-up.

\section{REFERENCES}

Aitken MJ, 1985. Thermoluminescence Dating. London, Academic Press: $359 \mathrm{pp}$

Aitken MJ, 1998. An Introduction to Optical Dating. Oxford, Oxford University Press: $276 \mathrm{pp}$.

Bhatia SB and Singh N, 1998. Middle Holocene palaeoclimatic and paleoenvironmental events, in southern Haryana. Proceeding Indian National Science Academy 54 A(4): 574-584.

Enzel Y, Ely LL, Mishra S, Ramesh R, Amit R, Lazar B, Rajaguru S.N, Baker V R ans Sandler A, 1999. High -Resolution Holocene Environmental Changes in Thar Desert, Northwestern India. Science 284: 1224-1228, DOI 10.1126/science.284.5411.125.

Ghose B, Kar A and Hussain Z, 1979. The lost courses of Saraswati River in the Great Indian Desert: New evidence from LANDSAT imagery. The Geographic Journal 145(3): 446-451.

Gupta AK, Sharma JR Sreenivasan G and Srivastava KS, 2004. New findings on the course of River Saraswati. Journal Indian Society of Remote Sensing 32(1): 1-24, DOI 10.1007/BF03030845.

Joshi JP, Madhu Bala and Jas Raj, 1984. The Indus Civilisation: A reconstruction on the basis of distribution maps. In: Lal BB and Gupta SP, eds., Frontiers of the Indus Civilisation. New Delhi, Books and Books: 511-539.

Murray AS and Roberts RG, 1998. Measurements of the equivalent dose in quartz using a regenerative-dose single aliquot protocol. Radiation Measurements 29: 501-515, DOI 10.1016/S13504487(99)00253-X

Murray AS and Wintle AG, 2000. Luminescence dating of quartz using an improved single-aliquot regenerative-dose protocol. Radiation Measurements 32: 57-73, DOI 10.1016/S1350-4487(99)00253-X.

Wintle AG and Murray AS, 2006. A review of quartz optically stimulated luminescence characteristics and their relevance in singlealiquot regeneration protocols. Radiation Measurements 41: 369391, DOI 10.1016/j.radmeas.2005.11.001

Oldham CF, 1893. The Saraswati and the lost river of the Indian desert. London. Journal Royal Asiatic Society 34: 49-76.

Pant NC, Saini HS, Mujtaba SAI and Tandon SK, 2005. Response of lake and dune systems to Holocene climate change: A study of the western plains of Haryana along northern margin of Thar desert. Geological Survey of India Records 137(8): 55-57.

Radhakrishna BP and Merh, eds., 1999. Vedic Saraswati, Evolutionary history of a lost river of Northwestern India. Memoir Geological Society of India 42: 329pp

Sahai B, 1999. Unraveling the lost Saraswati. In: Radhakrishna BP and Merh, eds., 1999. Vedic Saraswati, Evolutionary history of a lost 
river of Northwestern India. Memoir Geological Society of India 42: $121-141$

Saini HS and Anand VK, 1996. Lithostratigraphic framework and sedimentological evolution of the Quaternary deposits of northwestern Haryana. Geological Survey of India, Special Publication 21(2): 227-231.

Saini HS, Tandon SK, Mujtaba SAI and Pant NC, 2005. Lake deposits of the northern margin of Thar Desert: Holocene palaeoclimatic implication. Current Science 88 (12): 1994-2000.

Singh G, Joshi RD, Chopra SK and Singh AB, 1974. Late quaternary history of vegetation and climate of the Rajasthan Desert, India. London. Philosophical Transaction of the Royal Society, B267 : 467-501, DOI 10.1098/rstb.1974.0006.

Singh G, Wasson RJ and Agarwal DP, 1990. Vegetational and seasonal climatic changes since the last full glacial in the Thar desert, northwestern India. Review of Palaeobotany and Palynology 64 :351358, DOI 10.1016/0034-6667(90)90151-8.
Sood RK and Sahai B, 1983. Hydrographic changes in Northwestern India. Man and Environment VII : 166-169.

Stein A, 1942. A survey of ancient sites along the lost Saraswati river. Geographical Journal 99(4):173-182.

Thussu JL, 1995. Quaternary stratigraphy and sedimentology of the Indo-Gangetic Plains, Haryana. Journal of Geological Society of India 46 533-544.

Yash Pal, Sahai B, Sood RK, and Agarwal DP, 1980. Remote sensing of the "Lost" Saraswati river. Proceeding Indian National Science Academy (Earth and Planetry Sciences) 89(3): 317-331.

Wilhelmy H, 1969. The ancient river valley on the eastern border of the Indus plain and the Sarsawati problem. Zeitschrift fur Geomorphologie N.F. Suppl. Band 8: 76-93.

Wintle AG and Murray AS, 2006. A review of quartz optically stimulated luminescence characteristics and their relevance in singlealiquot regeneration protocols. Radiation Measurements 41: 369391, DOI 10.1016/j.radmeas.2005.11.001. 